\title{
Refugees and asylum seekers living in the Australian community: the importance of work rights and employment support
}

\author{
Caroline Fleay, Lisa Hartley and Mary Anne Kenny
}

\begin{abstract}
While Australian legislation allows for the mandatory detention of asylum seekers arriving without a valid visa, in recent years the Australian Government has released thousands from immigration detention prior to their protection claims being finalised. This article outlines the results of interviews with eleven men who had been released into such community-based arrangements after long periods of immigration detention. The major challenge for most of the men who had been granted the right to work upon their release was securing employment, while being denied the right to work was the major challenge for those released without this right. This article explores the social and personal benefits that employment can offer asylum seekers and refugees and the implications it has for integration into their host country.
\end{abstract}

Keywords: refugees, asylum seekers, work rights 


\section{Introduction}

Dawood Jan ${ }^{1}$ is an Afghan man of Hazara ethnicity who arrived in Australia by boat in May 2010 seeking asylum. He was held in immigration detention in remote north-western Australia for eighteen months, during which time his mental health deteriorated to the extent that he was prescribed antidepressant medication and was receiving regular counselling to cope with the trauma of potentially indefinite detention and waiting for his protection claim to be finalised. Part of Dawood Jan's anguish while in detention manifested as frequent nightmares, which meant he spent many nights reliving the violence he had fled in Afghanistan as well as the despair that he and others in long-term detention were enduring on a daily basis. He was finally released from detention in October 2012 and allowed to live in the community while processing of his protection claim continued.

Dawood Jan was initially placed into community detention for two months - a community-based arrangement that does not include the right to work. The support he received from extended family members and friends, case workers and a psychologist during this period of relative freedom enabled his mental health to begin to strengthen. However, his nightmares persisted as the initial feelings of immense relief at being released from detention soon gave way to boredom and anxiety. As Dawood Jan told one of the authors,

when I am in community detention I had lots of nightmares, when I was not allowed to work and I didn't have any job.

He was then granted a Bridging Visa E, which allows a person to live in the community while their claim for protection is processed. Once he was granted a Bridging Visa that allowed him the right to work, and was able to secure full time employment, Dawood Jan's nightmares subsided.

This article explores the implications of long-term immigration detention and the ability of refugees and asylum seekers to adjust to living in the community while their protection claims continue to be processed. We use the term 'refugee' for individuals whose refugee status has been recognised in Australia and 'asylum seeker' for those whose refugee status is yet to be determined. A permanent visa is not granted in Australia until it is found that a person both meets the legal definition of a 'refugee' and has been given a security clearance. Those who we refer to as 'refugees' had received notification that their refugee status was recognised by Australia. Some, however, had not (yet) been given a security clearance by the time of their interview, or were waiting for the outcome of a judicial review of their negative claim decision. For those recognised as refugees but who continued to wait for their security clearances to be finalised (see Table 1), their future in the community was still uncertain.

This article draws on interviews with eleven men who arrived by boat to Australia in 2010 seeking asylum, including Dawood Jan. All of the men interviewed endured lengthy periods of detention and were finally released into the community prior to their protection claims being finalised. As Dawood Jan's experiences suggest, being granted the right to work and having the capacity 
to find employment are important elements in restoring the mental wellbeing of those who have endured long-term detention. This is not to downplay the importance of the emotional and practical support provided by family, friends, case workers and other support professionals. However, in this article we seek to acknowledge and elevate the social and personal benefits that employment can offer asylum seekers and refugees, which can also facilitate their integration into the host country.

Australia, like many other industrialised countries, has introduced a variety of policy measures designed to deter the arrival of asylum seekers via its maritime boundaries using the language of 'border control'. It is essential to consider the experiences of asylum seekers themselves in policy debates because, as Korac argues, 'the refugee situation is generally framed...by an asymmetry of power and voice between the state on the one hand and the refugees on the other' (2003: 53). While acknowledging the importance of interrogating the power imbalances that exist between researchers and asylum seekers and refugees (Hugman et al. 2011: 1283-1284), including how the experiences expressed by interviewees are represented (Peters 2011: 709), this imbalance is not as stark as the imbalance of power between asylum seekers and refugees and the state. Research that elevates the experiences of refugees is essential in helping to reduce this asymmetry and highlight the impacts of deterrent-based policies on those most affected.

In this article we seek to highlight the experiences of asylum seekers and refugees who have borne the brunt of these policies. In doing so, the article raises specific concerns about recent Australian policy that denies the right to work to asylum seekers who arrived by boat to Australia from 13 August 2012. The findings from this article also have implications for other industrialised countries that deny or severely restrict asylum seekers' work rights.

This article is focused on employment, reflecting the importance placed on the right to work and being able to secure employment by the men interviewed in the study. The right to work is closely linked to human dignity. For marginalised groups, including asylum seekers and refugees, the ability to work is important not only as a means of subsistence, but also for self-realisation and social inclusion.

The right to work is articulated in a range of international human rights instruments that Australia has ratified, including the United Nations (UN) Convention Relating to the Status of Refugees (Refugee Convention) and the International Covenant on Economic, Social and Cultural Rights (ICESCR). The Committee on Economic Social and Cultural Rights has stated that the right to work is integral to enjoying other human rights:

Every individual has the right to be able to work, allowing $\mathrm{him} / \mathrm{her}$ to live in dignity. The right to work contributes at the same time to the survival of the individual and to that of his/ 
her family, and insofar as work is freely chosen or accepted, to his/her development and recognition within the community (Committee on Economic, Social and Cultural Rights 2006).

Similarly, the right to work has been considered to be one of the most important rights in the Refugee Convention (University of Michigan Law School 2010) and is recognised in articles 17, 18 and 19. The Refugee Convention makes some distinction between refugees 'lawfully in [a state's] territory' and refugees 'lawfully staying in [a state's] territory' in these articles, raising the issue of whether its provisions on the right to work can apply to asylum seekers within a territory whose protection claims have not yet been finalised. However, as argued by Lester, excluding asylum seekers from benefiting from the right to work provisions in the Refugee Convention

would, at best, inadvertently expose refugees deserving of these rights to violations of them. At worst, such an interpretation would represent a tantalising invitation to a more capricious government to make laws in bad faith which would obstruct the work rights of asylum seekers (2005: 354).

Denying asylum seekers and refugees the right to work is thus arguably in breach of these provisions. Mathew goes further and explains that 'there are strong legal arguments for permitting asylum seekers access to the employment market immediately, and they must certainly have access if asylum procedures are prolonged' (2012). This is reinforced by the recognition that the majority of asylum seekers who have arrived in Australia by boat over the past fifteen years have been recognised as refugees.

Articles in the ICESCR also outline rights to work. In particular, article 6 protects the rights to work of every person within a state's territory, including asylum seekers and refugees. Thus denying asylum seekers and refugees the right to work is arguably in breach of the ICESCR articles 6(1), 11 and 12, and is discriminatory (Taylor 2000). The ICESCR also outlines state obligations in terms of access to employment, including access to employment services and occupational training (Lester 2005). Hence not providing support to find employment is also arguably a breach of this Covenant.

In addition, denying the right to work to asylum seekers may result in destitution and force asylum seekers to seek work in unauthorised employment where labour conditions are more likely to be underpaid, dangerous and/ or degrading. This may therefore constitute a violation of the prohibition on inhuman or degrading treatment:

States are legally obliged to prevent and protect persons from such exploitation under, inter alia, the prohibition on inhuman and degrading treatment; the prohibition on slavery and forced labor; treaties for the suppression of human trafficking and people smuggling; and numerous treaties concerning non-discrimination (University of Michigan Law School 2010). 
Therefore, under international law, state signatories to the above instruments have obligations to adopt policies that allow asylum seekers and refugees the right to work and enable employment to be secured.

\section{Community-based arrangements for asylum seekers arriving in Australia by boat}

Over the past two decades successive governments of Australia have introduced policies directed towards people seeking to enter Australia by boat, primarily - and increasingly explicitly - focused on deterring boat arrivals. Since 1992 this has included a policy of mandatorily detaining all asylum seekers who arrive in Australia without a valid visa. The vast majority of such arrivals are asylum seekers arriving by boat and thus the policy effectively discriminates between boat arrivals and those who seek asylum once they are in Australia or arrive by plane (Viviani 1996). The Coalition Government from 1996 to 2007 significantly expanded this policy, opening new detention centres, often in remote locations, as well as introducing the offshore processing of asylum seekers on Nauru and Papua New Guinea's Manus Island. The explicit government aim was to deter the arrival of asylum seekers by boat (Briskman et al. 2008).

By the time of the 2007 federal election, these policies had meant that thousands had endured years in immigration detention before finally being accepted as refugees by Australia. In light of the evidence of the significant costs to the mental health of asylum seekers, opposition to detention policies grew within the community and some sections of the Coalition Government and the Labor Opposition (Fleay and Briskman 2013). Soon after winning the 2007 election, the Labor Government announced a set of values that would underpin detention policy for the new government. While maintaining the policy of mandatory detention, the values stated that children and their families should not be detained in immigration detention centres and that detention should only be used 'as a last resort and for the shortest practicable time' (Evans 2008: 7-8).

But with increasing numbers of boat arrivals, the Labor Government soon reinforced the indefinite nature of the mandatory detention policy and expanded the number of immigration detention centres. As the time taken by immigration authorities to finalise protection claims increased, so did the periods of detention (Fleay and Briskman 2013). Concerns increased regarding the impacts of long-term detention, and the Labor Government began to announce measures to allow for the release of some asylum seekers into the community while they waited for their claims to be finalised.

In October 2010, the Labor Government announced that it would expand its previously rarely used 'residence determination' power to place asylum seekers into a community detention environment by declaring it would move the majority of children and their families into community-based accommodation by June 2011 (Minister for Immigration and Citizenship and Prime Minister 2010). It was further announced on 25 November 2011 that following initial health, 
security and identity checks, other selected asylum seekers in detention would be placed into the community while their protection claims were finalised (Bowen 2011). This was to be achieved through extending the community detention program to vulnerable men, and releasing others on bridging visas.

The expansion of the community detention program and the process of issuing of bridging visas were welcome announcements given increasing reports of despair and mental health concerns in Australia's immigration detention centres throughout 2010 and 2011. By October 2011 there were 4,223 people in immigration detention, including 642 women and children: 2,100 had been detained for more than one year, 764 for more than eighteen months, and 86 for more than two years (Department of Immigration 2011). Since the announcements of the expanded community-based alternatives to detention for asylum seekers arriving by boat, thousands have been released from immigration detention centres (AHRC 2012). By the end of May 2013 there were 10,300 asylum seekers in the community on bridging visas and 2,800 individuals in community detention (Bowles 2013).

However, as asylum seekers continued to come to Australia by boat, and after a boat carrying asylum seekers sank in June 2012, the Labor Government established an expert panel to review current policies. The panel was tasked with providing advice on asylum seeker issues including 'how best to prevent asylum seekers risking their lives by travelling to Australia by boat' (Prime Minister of Australia 2012). The Report of the Expert Panel on Asylum Seekers recommended the government adopt a policy of 'no advantage' that was to ensure 'that those who choose irregular and dangerous maritime voyages to Australia in order to seek asylum are not advantaged over those who seek asylum through regular migration pathways and established international arrangements' (Australian Government 2012: 20). The 'no advantage' policy was applied to asylum seekers who had arrived by boat after 13 August 2012. This meant that the protection claims of asylum seekers who came to Australia by boat after this date would not be processed any faster than if they had remained in transit countries such as Indonesia or Malaysia, or in their neighbouring countries.

The Expert Panel Report also recommended sending asylum seekers to regional processing centres on Nauru or Papua New Guinea's Manus Island as a disincentive for other asylum seekers to come by boat. The Labor Government duly established regional processing centres on both islands. As at the end of September 2013, there were 1,566 asylum seekers detained on the islands, where they wait for their refugee claims to be processed under local laws (Maley and Wilson 2013). As more asylum seekers continued to arrive than could be sent to the regional processing centres, the Labor Government declared in November 2012 that asylum seekers who arrived by boat after 13 August 2012 and who had not yet been sent to Nauru and Manus Island could be released from detention on a community-based arrangement with limited entitlements and no right to work (Bowen 2012). As at November 2013, there are some 27,000 asylum seekers in Australia in this situation (Cash 2013: 45). 
In the wake of the election of the Coalition Government in September 2013, these asylum seekers continue to face uncertainty over when their claims will be processed. The Coalition Government also attempted to reintroduce temporary protection visas (TPVs) for those who would be recognised as refugees. ${ }^{2}$ These visas would be granted for a maximum of three years and, while they would include the right to work, they would not include the right to family reunion nor travel outside Australia. They would also require another attempt to claim asylum near the time of visa expiry in order for a further TPV to be secured (Department of Immigration 2013).

While the regulation enabling TPVs was blocked in the Australian Senate on 2 December, the Coalition Government may again introduce it to Parliament after six months. Should these visas be implemented at that point, there would be no prospect for asylum seekers now in Australia to secure a permanent visa. In the meantime, in the absence of TPVs, the Coalition Government is refusing to process any refugee claims of asylum seekers in Australia (Minister for Immigration and Border Protection 2013). Given the processing backlog already faced by the Department of Immigration and Border Protection, it is now even more likely that these asylum seekers will face months if not several years in the community without the right to work while they wait for their refugee claims to be finalised. Thus while the research outlined in this article was conducted with asylum seekers who arrived prior to 13 August 2012, their experiences of living in community-based arrangements have important implications for the policies applied to those who have more recently arrived.

\section{Bridging Visa $\mathrm{E}$}

Asylum seekers and refugees in immigration detention in Australia may be released from detention on a Bridging Visa $\mathrm{E}$ (BVE). For those who arrived by boat prior to 13 August 2012, this allows them to remain lawfully in Australia while their protection claim is processed and their immigration status is resolved. These BVE holders are entitled to six weeks of transitional funding and support provided by the Department of Immigration upon their release from detention - this is known as Transitional Community Assistance Support (CAS). According to the Australian Red Cross, contracted by the Department of Immigration to provide this support, the level of support provided under Transitional CAS is based on individual needs. It may include emergency accommodation; information that helps to find longer-term accommodation; orientation to the community; organisation of healthcare appointments; assistance to open a bank account; advice on how to find a job; financial assistance (equivalent to 89 per cent of the Australian Government standard welfare benefit); rent assistance (equivalent to 89 per cent of the Australian Government standard rent assistance); and financial assistance to contribute to meeting the cost of health-related expenses (Australian Red Cross 2012a). After the six-week transition period, BVE holders who are assessed as requiring additional assistance may receive further support. BVE holders who arrived prior to 13 August 2012 also have the right to work. 


\section{Community Detention}

Asylum seekers and refugees assessed as the most vulnerable in Australia's immigration detention network can be released into the Community Detention (CD) program. This includes unaccompanied children, families with children, people with severe mental or physical health issues, and survivors of torture and trauma. Those in CD are subject to conditions including not having the right to work and the requirement to reside at an address outside a detention centre that has been designated by the Minister for Immigration. There is also a requirement to regularly report to the Department of Immigration or a relevant service provider. According to the Department, the support and services provided to those in CD include accommodation (rent-free) with furniture and household goods (owned by the Department); 24-hour care for unaccompanied children; assistance to access healthcare; education for school-age children; access to meaningful activities (Department of Immigration 2012); and income support equivalent to 70 per cent of the Australian Government standard welfare benefit for those who arrived prior to 13 August 2012 (Victorian Refugee Health Network 2012).

\section{Method and study participants}

This study examined the experiences of asylum seekers and refugees released from long-term detention into the community in Australia while their protection claims are finalised. Documenting such experiences has not been the subject of formal research to date. Eleven men living in community-based arrangements after their release from long periods of detention were interviewed for this study. The semi-structured, in-depth interviews were conducted by the authors and interpreters were used when required. Each of the men was asked questions relating to their experiences living in community-based arrangements with regards to employment, housing, health, their formal and informal support networks, their sense of belonging and identity, and any other issues they identified as important. These questions were based on the United Nations High Commissioner for Refugees (UNHCR) recommended basic reception standards for asylum seekers. These include the right to formal documentation legitimising their status in the community; the right to an adequate standard of living; and the right to assistance to access what is necessary not only for survival but also for a life of dignity, such as appropriate accommodation, health care, education, and employment or financial support (UNHCR 2000).

The interviews were conducted with eleven men living in five Australian capital cities (Adelaide, Brisbane, Canberra, Sydney, Perth) between June and September 2012 either by phone or in person. All of the men interviewed had spent the majority of their time in detention at the Curtin Immigration Detention Centre (Curtin IDC) in remote north-western Australia. As detailed in Table 1, they were held in immigration detention for periods of between 15 and 25 months. Eight of the men interviewed had come from Afghanistan, two from Sri Lanka and one from Iran. Seven of the men interviewed had lived in the community 
after being issued with a BVE, and one had been released from detention into $\mathrm{CD}$ and subsequently issued with a BVE after two months. The other three men were or had been living in the CD program.

Table 1 - Participant Details

\begin{tabular}{|c|c|c|c|c|c|c|c|}
\hline $\begin{array}{l}\text { Name of } \\
\text { Participant }\end{array}$ & $\begin{array}{l}\text { Country } \\
\text { of Origin }\end{array}$ & Status & $\begin{array}{l}\text { Months in } \\
\text { Detention }\end{array}$ & $\begin{array}{l}\text { Months in } \\
\text { Community- } \\
\text { Based } \\
\text { Arrangement }\end{array}$ & $\begin{array}{l}\text { Months } \\
\text { with } \\
\text { Permanent } \\
\text { Visa }\end{array}$ & $\begin{array}{l}\text { Right } \\
\text { to Work }\end{array}$ & $\begin{array}{l}\text { Previous } \\
\text { Employment }\end{array}$ \\
\hline Ali & Afghanistan & Refugee & 20 & 2.5 (BVE) & 2 & Yes & $\begin{array}{l}\text { Farming, building } \\
\text { construction, } \\
\text { marble work }\end{array}$ \\
\hline Dawood Jan & Afghanistan & Refugee & 18 & $\begin{array}{l}2 \text { (CD) and } \\
5.5 \text { (BVE) }\end{array}$ & - & Yes & $\begin{array}{l}\text { Barista, baker, } \\
\text { café management }\end{array}$ \\
\hline Hussain & Afghanistan & Refugee & 21 & 5 (CD) & 1 & No & $\begin{array}{l}\text { Shoemaking, } \\
\text { management of } \\
\text { business }\end{array}$ \\
\hline Kaly & Sri Lanka & Refugee & 16 & 9 (BVE) & - & Yes & $\begin{array}{l}\text { Information } \\
\text { technology }\end{array}$ \\
\hline Kumaran & Sri Lanka & $\begin{array}{l}\text { Asylum } \\
\text { Seeker }\end{array}$ & 25 & 3 (CD) & - & No & $\begin{array}{l}\text { Bar and hotel } \\
\text { work }\end{array}$ \\
\hline Mahmoud & Iran & $\begin{array}{l}\text { Asylum } \\
\text { Seeker }\end{array}$ & 15 & 9 (CD) & & No & Engineering \\
\hline Mohammad & Afghanistan & Refugee & 19.5 & 3 (BVE) & 1.5 & Yes & $\begin{array}{l}\text { Building } \\
\text { construction, } \\
\text { sewing rugs }\end{array}$ \\
\hline Reza & Afghanistan & Refugee & 20 & 6 (BVE) & 1 & Yes & $\begin{array}{l}\text { Building } \\
\text { construction }\end{array}$ \\
\hline Raza & Afghanistan & $\begin{array}{l}\text { Asylum } \\
\text { Seeker }\end{array}$ & 21 & 5 (BVE) & - & Yes & Unknown \\
\hline Sakhi & Afghanistan & Refugee & 21.5 & 4 (BVE) & - & Yes & $\begin{array}{l}\text { Building } \\
\text { construction }\end{array}$ \\
\hline Sayed & Afghanistan & Refugee & 20 & 4 (BVE) & 2 & Yes & $\begin{array}{l}\text { Plastering, fruit } \\
\text { picking, rug } \\
\text { making }\end{array}$ \\
\hline
\end{tabular}

\section{The right to work and finding employment}

The interviewees spoke of a range of factors that have had an impact on their experiences in the community after long-term detention - such as the mental distress that had emerged during their long-term detention, the level of support they received from service providers, and access to appropriate healthcare. However, the right to work and finding employment was the overwhelming concern for most of them. After their release from detention they described the biggest challenge as being denied the right to work (for those in CD) or finding paid employment (for those on BVEs). All of the interviewees expressed a desire and motivation to work. 
All three of the men in CD reported wanting the right to work and described their experience of being in CD as a time of loneliness, boredom and waiting. As outlined earlier, Dawood Jan experienced a marked improvement in his mental health once he was moved from CD and issued a BVE and had found paid employment. Kumaran, ${ }^{3}$ who was in CD when he was interviewed, had anticipated that finding employment would have similar benefits for him. With his excellent English language skills and employment experience in his own country, he felt confident that he could find a job if he was given the right to work. Instead, he felt forced to stay idle, which compounded his growing anxiety about the uncertainties of his protection claim, and his worries for his family back home:

When I go out and meet my friends on BVs their lives are busy and they can come late at night and they can go to job. They seem to be busier than me and I am always sitting at home with nothing to do (Kumaran, asylum seeker).

After the short-lived relief of being released from immigration detention, Kumaran's experience of CD without the right to work began to replicate his detention experience and reinforce his sense of isolation from others:

When I came out [of detention] it was a feeling like I am much much different than others. Still I have that feeling. Still I have that feeling because others are busy and everything and I feel like I am sitting down and I see they are much different than me, I feel they are much different than me...It's like I'm looking at things from the outside, I'm not inside...I am in large detention, no wires at all, no fences around, but still large detention (Kumaran, asylum seeker).

While the men on BVEs all had the right to work, the biggest challenge cited by five of the eight men interviewed on BVEs was finding employment. Four of the eight interviewees on BVEs had found full-time employment and one had found part-time work. The remaining three men continued to search for employment. Of the other three men interviewed on BVEs, one cited the difficulties associated with not knowing the culture and language of his new country as constituting the greatest challenge, which he later said were important factors that prevented him from finding employment. In contrast, Kaly's ${ }^{4}$ English language skills were excellent, he possessed professional skills from his employment prior to arriving in Australia, and he had very supportive informal networks, which all contributed to his gaining employment within a few months of his release from detention. The biggest challenge for Kaly had been the loss of confidence and feeling of being dehumanised that he experienced while in long-term detention. The biggest challenge cited by Raza was the distress he experienced upon being told that his protection claim had been finalised and a negative decision issued, and that he would have to return to Afghanistan. 


\section{The right to work and restoring feelings of self-worth}

The words of the men we interviewed reflect the central role that gaining employment plays in the lives of people who have endured persecution in their own countries, the often difficult and dangerous journeys of flight, and then the enormous challenges of trying to reestablish their lives in a new country. As with human beings in general, for asylum seekers and refugees work is 'fundamental to human dignity. It is central to survival and development of the human personality' (University of Michigan Law School 2010: 293).

It was clear from our interviewees that not only does paid employment help to enable asylum seekers and refugees to support themselves and their families, it also 'contributes enormously to the individual's sense of self-worth' (Taylor 2000: 87) and is 'a significant source of empowerment' (Da Lomba 2010: 424). It was this aspect that was most apparent to the authors during the interviews. It was also apparent when one of the authors met with Kumaran four months after his interview. This was two months after he had been given a BVE and the right to work, and he had just received news that he had been recognised as a refugee, although he continued to wait for the grant of a permanent visa pending his security clearance. In relation to obtaining the right to work, he remarked that

it feels good because I am on my own, because I am working. I am on my own, I'm not depending on Australia, on anyone, and I can take care of my family back home (Kumaran, personal communication, 22 November 2012).

Kumaran's pride at having secured full-time employment, and being able financially to support his family in his home country, was clearly evident. Despite still waiting for the final decision on his protection claim, his sense of self-worth was much improved and the immense satisfaction he was gaining from working long hours was obvious.

This sense of pride and self-worth obtained from employment is consistent with research conducted on asylum seekers and refugees in relation to social exclusion in the Unied Kingdom:

Gaining refugee status and being able to participate in the labour market marked a significant turning-point in the lives of those interviewed. This change in immigration and employability status made interviewees feel 'much more positive about life'... Those that had gained employment emphasised the positive psychological impact of having a job and being independent (Phillimore and Goodson 2006: 1729).

Being granted the right to work, and being able to find employment, is also central to restoring feelings of self-worth that greatly diminish during periods of long-term detention. Diminished feelings of self-worth are reflected in the development of mental health problems that research has associated with long periods in immigration detention (Coffey et al. 2010; Silove et al. 2010). For 
example, in a comparison of the medical needs of a group of asylum seekers living in the community in Melbourne, Australia in 2001-2003, Mitchell and Kirsner found that 'asylum seekers released from detention were three times more likely to seek medical attention, particularly from mental health services, than those asylum seekers who have never been in detention' (2004: 122). The distress resulting from long-term immigration detention can also exacerbate the mental health impacts of torture and trauma that asylum seekers may have experienced prior to their arrival to Australia.

All of the men we interviewed spent long periods of time in immigration detention facilities - between 15 and 25 months - and some spoke about the despair and anguish they experienced during detention:

I never believed I was going out of this detention...I was totally hopeless, I just totally lost my hope of getting free (Mohammad, refugee).

Some described that their experience in detention of guards remaining constantly in their presence persisted with them following their release:

All that time I was scared, I was thinking there was someone behind me, leading me, stopping me...don't do this or do this, you are not allowed to do this, you are not allowed to do that (Sakhi, refugee).

Kaly described how difficult he had found it to talk with other people during the weeks following his release from sixteen months in detention:

It was really hard for me to socialise with people...I couldn't talk to people. I wasn't able to socialise. I would just stay and listen to people. But now, I've changed. I have friends. But that was the worst experience for me I would say. Because I was exactly the opposite before detention. I would talk to anyone. [I was] really open (Kaly, asylum seeker).

As experienced by Kaly, immigration detention provides an institutional barrier between asylum seekers and the rest of the community, 'discourag[ing] connections between detainees and the outside world' (Klein \& Williams 2012: 741). For those who endure long-term detention, and particularly for those such as our interviewees, who were detained in remote locations, there is a need for significant support to be provided to facilitate their access to the wider community upon their release. This includes having the right to work, and support to find employment.

\section{Non-legal barriers to finding employment}

While the right to work was seen as an important factor to restoring self-worth after long-term detention, a number of non-legal barriers to finding employment were highlighted as presenting significant challenges for some of the interviewees. One of the major barriers to finding employment cited was the lack of formal support provided to do so. While all of the men on 
BVEs expressed great motivation and gave examples of being proactive in attempting to secure employment, none had acquired paid work through formal support services such as their case worker. While some of the men said their case workers had suggested they would provide assistance, very little was forthcoming. This is consistent with the limited employment support provided to asylum seekers released from detention on BVEs with work rights through the Department of Immigration-funded programs. The support includes advice about seeking employment - such as assistance with curriculum vitaes or direction to appropriate internet websites - and referral to other services (Australian Red Cross 2012a; 2012b). This is not sufficient support to ensure people are able to secure and retain employment.

As recalled by Sakhi, ${ }^{5}$ the tension between wanting to obtain employment and not having enough information to do so was a frustrating experience:

Because I [am a] good worker, I like to find a good job, because I have good experience in my own country, I am good [in] construction... but I can't find you know. I can work with the good company you know, other organisation [for] small price you know... but unfortunately at the moment I can't find and I don't have any information (Sakhi, refugee).

For the five interviewees who had found employment, four of them had secured work through their informal support networks. Kaly described the importance of his contacts with asylum seeker advocates that he had met while in detention:

Pretty much all the jobs I have now are because I was connected to the advocates... It would have been really hard for me if I didn't have all these friends (Kaly, asylum seeker).

The exception to this reliance on informal networks was Dawood Jan, who had been able to use his excellent English language skills and previous experience of living in a western country in order to find employment. He developed a resume with the assistance of an advocate and began approaching prospective employers himself in order to find work.

Most of the men identified the temporary status of being on a BVE as a significant barrier to finding employment. Sayed commented that he had applied for many jobs and been told that 'he needed to be a permanent resident'. Similarly, Mohammad said that his 'biggest problem' continued to be finding a job and that the temporary status of being on a BVE made him feel like a 'person without any future'. He spoke of feeling stuck - having the right to work but unable to gain employment because he did not have 'legitimate' identity documents:

Even in meat factory they are not employing the people who has BV because what they are saying that this visa is not valid, we don't know how long you are going to stay, you are not staying, you haven't been a proper Australian (Mohammad, refugee). 
The experiences of the men interviewed for this research are similar to those outlined in research conducted with refugees who held TPVs. These visas were granted to people who were found to be refugees and had arrived in Australia in an 'unauthorised way' - primarily those who arrived by boat - and provided permission for the holder to remain in Australia on a three-year temporary basis. The TPV was introduced by the Coalition Government in Australia in 1999 and remained in place until abolished by the Labor Government in 2008. Research demonstrated the negative impact of TPVs upon labour participation by refugees. The temporary nature of the visa was of itself a significant barrier to obtaining employment. TPVs provided 'the grounds for discrimination by employers', with refugees reporting that some employers had no understanding that TPV holders had the right to work, and some employers exhibited racist and/or ageist attitudes, particularly in relation to older refugees looking for work (Marston 2004: 71-72).

Limited English was a major barrier to securing employment for some of our interviewees, as found in other research on the experiences of asylum seekers and/or refugees (Da Lomba 2010; Marston 2004; Phillimore \& Goodson 2006). Being illiterate in English, Reza ${ }^{6}$ had not been able to look for employment through newspapers or the internet and was totally reliant on friends and word of mouth. On one occasion he secured a meeting with a manager of a factory but described his lack of English as being the reason why he was not awarded the job:

Finding a job has been the hardest thing for me. To find a job you need to speak good English and you need to know people. If you don't have English, forget it (Reza, refugee).

The experiences of Dawood Jan and Kaly in securing full-time employment reinforce the importance of good English language skills. Both have excellent English, which assisted them in obtaining support from local refugee advocates as well as in securing full-time employment. In addition, both Dawood Jan and Kaly had prior experiences living in western countries before arriving in Australia, which may have also facilitated their entry into the labour market. This is consistent with Australian research that has found that refugees who are perceived as racially and culturally different from the mainstream often experience more difficulty in gaining employment in the first instance. When employment is gained, it is more likely to be in the secondary labour market, such as cleaning services, aged care, building and meat processing (Colic-Peisker \& Tilbury 2006).

Unfortunately, BVE holders have limited access to English as a Second Language (ESL) classes. Access to ESL classes varies between and within states, and is dependent upon the resources and capacities of local service providers. None of our interviewees accessed any ESL classes other than short-term sessions. This limited access to adequate language tuition hinders the development of English language skills, which are vital to securing employment opportunities in Australia (Waxman 2001). As found in research with refugees in the United 
Kingdom (Da Lomba 2010), it is also likely to inhibit the capacity of asylum seekers and refugees in Australia to develop social connections with others in the community, such as teachers and fellow students.

In addition to adequate English language tuition, formal employment support and assistance are required for asylum seekers and refugees' skills and experience to be put to good use in Australia (Croucher 2007). All of the interviewees for this study had employment experience prior to their arriving in Australia. Some have considerable experience in building construction, plastering and hospitality, and two have professional qualifications in engineering and information technology (see Table 1). All could benefit from the creation of employer education campaigns and employer liaison programs that might assist in finding employers who would benefit from their skills and experience. Such campaigns and programs could draw on the experiences of a program run by the Brotherhood of St Laurence in Melbourne, and similar employment schemes in Europe (Marston 2004).

Our interviews reinforce the findings of research that explore the barriers to finding employment faced by resettled refugees (for example, see Croucher 2007; Hugo 2011; Colic-Peisker \& Tilbury 2006; Phillimore \& Goodson 2006; Waxman 2001). However, the temporary nature of a BVE and the limited entitlements that are attached to the visa are clearly additional barriers to finding and securing employment for the refugees and asylum seekers we interviewed.

\section{Integration and the right to work}

In the above sections we have outlined the factors that were raised by the interviewees with regard to work rights. Building on these themes, in this section we consider the broader implications of the right to work and social integration. Much of the literature drawn on in this section discusses integration in the context of the resettlement experiences of people already recognised as refugees. However, the emphasis placed on integration as a process that commences at the time of arrival in what may become a host country suggests that this literature is relevant for asylum seekers who are yet to be recognised as refugees.

Integration into a society is an essential part of providing a durable solution for refugees. A process of integration:

will be successful and lasting only if it allows the refugee to attain a degree of self-sufficiency, to participate in the social and economic life of the community and to retain what might be described... as a degree of personal identity and integrity (Goodwin-Gill 1990: 38).

Such a process suggests that refugees need to be enabled to participate as equals with the citizens of a host country and that this is 'contingent on securing paid employment, [as well as] re-establishing family relationships, accessing educational opportunities and securing affordable and appropriate housing' (Marston 2004: 68). Research also suggests that people who are provided with 
access to the above as soon as they arrive in a country are able to integrate into their host society to a greater extent than those who are not provided with such early access (Korac 2003; Valenta and Bunar 2010).

This is an understanding of integration as a process, rather than an endpoint, that commences on the first day of arrival in a place that he or she considers as their destination (Ager and Strang, 2008; Losi and Strang 2008). For those with uncertainty as to obtaining permanent legal status at their intended destination, the process of integration may be hindered. This appears to be the case for those interviewed in this research. Further, integration is understood as a two-way process in which both refugees and the host country have responsibilities and adaptation requirements, such as the latter's responsibility to provide access to appropriate language tuition and employment opportunities (Phillimore \& Goodson 2006). Thus if host countries fail to interpret integration as a two-way process, then states are not likely to provide the assistance refugees need in order to integrate (Da Lomba 2010). This highlights the responsibilities that states have to enact policies that facilitate the integration of refugees, including avoiding lengthy periods of immigration detention. These responsibilities also relate to the right to work and the ability to find employment.

It is often argued that employment is the most important factor in enabling the integration of migrants into a host society (Phillimore \& Goodson 2006; Valenta \& Thorshaug 2012; Valtonen 1998). This is not only because of the obvious economic benefits for refugees, but also due to the social and personal benefits. Employment allows for the development of social relations with cultural communities beyond the family and immediate ethnic networks. It also enhances local language competencies. If the right to work is denied, or little or no assistance provided to find employment, then refugees will be largely excluded from formal labour markets. This means that their opportunities to engage in 'social contact with other groups' will be minimised, given that workplaces in the formal labour market are important sites of such engagement (Marston 2004):

Those who remain unemployed from the outset of resettlement, or for long periods, are at risk of becoming socially excluded from the mainstream, since, for newcomers, the main source of regular social contact with other groups is often through the workplace (Valtonen 1998: 45).

Such exclusion may force refugees to engage in the informal labour sector (Valenta \& Thorshaug 2012) or to become dependent on state welfare or community sector support (Zimmermann 2009). Studies have found that refugees do not generally enter host countries with the intention of accessing welfare support - most want to gain employment (Phillimore \& Goodson 2006; Valtonen 1998; Zimmerman 2009). The motivation of all of our interviewees to find employment suggests such a desire: to support themselves and their families financially rather than rely on welfare support. Granting asylum seekers and refugees the right to work supports this desire for self-reliance. 


\section{Conclusion}

The right to work, and the ability to secure employment, was the major challenge faced by most of the eleven men we interviewed in 2012. Our interviews also highlighted that the right to work and the capacity to secure employment can assist in the restoration of feelings of self-worth and improvement in mental health in general that deteriorated during long periods of immigration detention.

While the Australian Government has granted some asylum seekers and refugees who arrived prior to 13 August 2012 the right to work, they have provided little assistance to secure employment. Those interviewed were not entitled to receive formal support in finding employment and they also received little access to English language tuition. This suggests an understanding of integration that is one-way (Da Lomba 2010) in that it has been largely left to the asylum seekers and refugees themselves to try to secure employment and cope as best they can with their existing English language competencies. For our interviewees in CD, there was no legal right to work granted and thus no prospect of engaging in formal employment. Those we interviewed on BVEs may have had the legal right to work, but non-legal barriers to finding employment were not actively addressed.

An understanding of integration as a two-way process considers that it commences the day of arrival in Australia. For our interviewees, their first 15-25 months in Australia were spent in the form of indefinite detention. Upon their release from detention, those granted BVEs were at least given the legal right to work and the opportunity to engage in an integration process into their host society. Those placed in CD were not, experiencing one of the legal barriers to integration in the form of being refused the right to work. Given that eight interviewees had been found to be refugees by the time of their interviews, and had the legal right to remain permanently in Australia, this means their opportunity and capacity to integrate had been severely curtailed for many months to years. As the other three interviewees may yet be recognised as refugees, this may also be the case for them.

Our findings have important implications for current Australian policy, which denies the right to work to asylum seekers who came to Australia by boat after 13 August 2012 and are living in the community on bridging visas. To date (November 2013) none have had their protection claims finalised and most have received no indication of when this may commence. Therefore they will likely face months if not several years in the community on bridging visas pending finalisation of their protection claims with no right to work.

Given that figures show between 70 and 97 per cent of asylum seekers who have arrived in Australia by boat over the past fifteen years have eventually been found to be refugees (for example, see Phillips 2011), it is very likely that a significant proportion of asylum seekers who are currently being denied work rights are likely to be refugees. While these asylum seekers may not experience the lengthy periods of detention that our interviewees have endured, it is still 
apparent that distress can emerge after short periods of detention. In addition, they will face insecurity and the associated negative impact upon mental health that accompanies the lengthy periods of uncertainty around the outcome of their protection claim. Not having the right to work will exacerbate this anguish, despite at least being able to live outside a closed detention environment. Therefore, given what we have argued above regarding the impacts of not having work rights, it is ethically unjustified to impose this policy once again.

\section{Acknowledgements}

This research was funded by a Curtin University Humanities Publication Grant. The authors would also like to thank the two anonymous reviewers for their feedback on an earlier draft.

\section{References}

Ager, A. \& Strang, A. (2008) 'Understanding integration: A conceptual framework', Journal of Refugee Studies, 21 (2), 166-191.

AHRC (2012) Community Arrangements for Asylum Seekers, Refugees and Stateless Persons: Observations from Visits Conducted by the Australian Human Rights Commission from December 2011 to May 2012, http:/www.humanrights.gov.au/sites/default/files/content/human_ rights/immigration/2012community-arrangements/community_based_ arrangements.pdf

Australian Government (2012) Report of the Expert Panel on Asylum Seekers, August 2012, http://expertpanelonasylumseekers.dpmc.gov.au/report

Australian Red Cross (2012a) Fact Sheet Migration Support Programs: Transitional Community Assistance Support, http://www.redcross.org.au/ files/20120816_CAST_FACTSHEET.pdf

Australian Red Cross (2012b) Fact Sheet Migration Support Programs: Asylum Seeker Assistance Scheme, http://www.redcross.org.au/files/20120203_ ASAS_Fact_Sheet_.pdf

Bowen, C. (2011) Bridging visas to be issued for boat arrivals, Minister for Immigration and Citizenship Media Release, 25 November, http://www. minister.immi.gov.au/media/cb/2011/cb180599.htm

Bowen, C. (2012) No advantage onshore boat arrivals, Minister for Immigration and Citizenship Media Release, 21 November, http://www.minister.immi. gov.au/media/cb/2012/cb191883.htm

Briskman, L., Latham, S. \& Goddard, C. (2008) Human Rights Overboard: Seeking Asylum in Australia, Carlton North, Scribe Publications.

Cash, M. (2013) Evidence to Senate Legal and Constitutional Committee, Parliament of Australia, Canberra, 19 November 2013. 
Coffey, G.J., Kaplan, I., Sampson, R.C. \& Montagna Tucci, M. (2010) 'The Meaning and Mental Health Consequences of Long-term Immigration Detention for People Seeking Asylum', Social Science and Medicine 70 (12), 2070-2079.

Colic-Peisker, V. \& Tilbury, F. (2006) 'Employment Niches for Recent Refugees: Segmented Labour Market of the 21st Century Australia', Journal of Refugee Studies, 19 (2), 203-229.

Committee on Economic, Social and Cultural Rights (2006) The Right to Work: General Comment no. 18, UN Doc E/C.12/GC/18, para 1.

Croucher, G. (2007) 'A chance to contribute: Some remarks on the potential economic impact of allowing asylum seekers the right to work', Just Policy, 44, 37-43.

Da Lomba, S. (2010) 'Legal status and refugee integration: A UK perspective', Journal of Refugee Studies, 23 (4), 415-436.

Department of Immigration (2011) Immigration Detention Statistics Summary 31 October 2011, www.immi.gov.au/managing-australias-borders/ detention/facilities/statistics/

Department of Immigration (2012) Fact Sheet 83a - Community Detention, May 2012, http://www.immi.gov.au/media/fact-sheets/83acommunitydetention.htm

Department of Immigration (2013) Amendments to the Migration Regulations 1994 relating to Temporary Protection Visas Commencement: 18 October 2013, http://www.immi.gov.au/legislation/amendments/2013/131018/ lc18102013-01.htm

Evans, C. (2008) 'New Directions in Detention, Restoring Integrity to Australia's Immigration System', Seminar Centre for International and Public Law, Australian National University, 29 July.

Fleay, C. \& Briskman, L. (2013) 'The Hidden Men', Refugee Survey Quarterly, $32,112-129$.

Goodwin-Gill, G. (1990) 'Refugee or Asylum: International Law and the search for solutions to the Refugee problem'. In H. Alderman \& C.M. Lanphier (eds) Refuge or Asylum: A Choice for Canada, Toronto, York Lane Press.

Hartley, L. \& Fleay, C. (2012) 'Released but Not Yet Free: Refugees and Asylum Seekers in the Community after Long-term Detention', Australian Policy Online, 31 December, http://apo.org.au/research/released-not-yet-freerefugees-and-asylum-seekers-community-after-long-term-detention

Hugman, R., Pittaway, E. \& Bartolomei, L. (2011) 'When “Do No Harm” is Not Enough: The Ethics of Research with Refugees and Other Vulnerable Groups', British Journal of Social Work, 41, 1271-1287. 